NOTICE: this is the author's version of a work that was accepted for publication in Geochimica et Cosmochimica Acta. Changes resulting from the publishing process, such as peer review, editing, corrections, structural formatting, and other quality control mechanisms may not be reflected in this document. Changes may have been made to this work since it was submitted for publication. A definitive version was subsequently published in GEOCHIMICA ET COSMOCHIMICA ACTA, 75 (11), 2011, http://dx.doi.org/10.1016/j.gca.2011.03.015 


\title{
Absence of seasonal patterns in MBT-CBT indices in mid-latitude soils
}

\author{
Johan W.H. Weijers ${ }^{1 *}$, Beth Bernhardt ${ }^{2} *$ Francien Peterse $^{3 *}$, Josef P. Werne ${ }^{2,4}$, Jennifer A.J. \\ Dungait $^{5}$, Stefan Schouten ${ }^{3}$ and Jaap S. Sinninghe Damsté ${ }^{1,3}$
}

${ }^{1}$ Department of Earth Sciences - Geochemistry, Utrecht University, P.O. Box 80.021, 3508 TA Utrecht, The Netherlands;

${ }^{2}$ Large Lake Observatory and Department of Chemistry \& Biochemistry, University of Minnesota Duluth, 10 University Dr., Duluth, MN, USA;

${ }^{3}$ Department of Marine Organic Biogeochemistry, Royal Netherlands Institute for Sea Research (NIOZ), P.O. Box 59, 1790 AB Den Burg-Texel, The Netherlands;

${ }^{4}$ work prepared while on leave at the Centre for Water Research, University of Western Australia, Crawley, Western Australia and WA-Organic and Isotope Geochemistry Centre, Curtin University of Technology, Bentley, Western Australia;

${ }^{5}$ Sustainable Soils and Grassland Systems Department, Rothamsted Research-North Wyke, Okehampton, Devon, EX20 2SB, United Kingdom.

* These authors contributed equally to this work

ๆ Corresponding author: j.weijers@geo.uu.nl 


\section{Abstract}

2 The degree of methylation and cyclisation of bacteria-derived branched glycerol dialkyl glycerol

3 tetraether (GDGT) membrane lipids in soils depends on temperature and soil pH. Expressed in

4 the Methylation index of Branched Tetraethers (MBT) and Cyclisation ratio of Branched

5 Tetraethers (CBT), these relationships are used to reconstruct past annual mean air temperature

6 (MAT) based on the distribution of branched GDGTs in ancient sediments; the MBT-CBT

7 proxy. Although it was shown that the best correlation of this proxy is with annual MAT, it

8 remains unknown whether a seasonal bias in temperature reconstructions could occur, such as

9 towards a seasonal period of 'optimal growth' of the, as yet, unidentified soil bacteria which

10 produce branched GDGTs. To investigate this possibility, soils were sampled from eight

11 different plots in the U.S.A. (Minnesota and Ohio), The Netherlands (Texel) and the U.K.

12 (Devon) in time series over one year and analyzed for their branched GDGT content. Further

13 analyses of the branched GDGTs present as core lipids (CLs; the presumed fossil pool) and

14 intact polar lipids (IPLs; the presumed extant pool) were undertaken for two of the investigated

15 soil plots. The amount of IPL-derived branched GDGTs is low relative to the branched GDGT

16 CLs, i.e. only $6-9 \%$ of the total branched GDGT pool. In all soils, no clear change was apparent

17 in the distribution of branched GDGT lipids (either core or IPL-derived) with seasonal

18 temperature change; the MBT-CBT temperature proxy gave similar temperature estimates year-

19 round, which generally matched the mean annual soil temperature. In addition to a lack of

20 coherent changes in relative distributions, concentrations of the branched GDGTs did not show

21 clear changes over the seasons. For IPL-derived GDGTs these results suggest that their turnover

22 time in soils is in the order of one year or more. Thus, our study does not provide evidence for

23 seasonal effects on the distribution of branched GDGTs in soils, at least at mid-latitudes, and

24 therefore no direct evidence for a bias of MBT-CBT reconstructed temperatures towards a

25 certain season of optimal growth of the source bacteria. If, however, there is a slight seasonal

26 preference of branched GDGT production, which can easily be obscured by natural variability

27 due to the heterogeneity of soils, then a seasonal bias may potentially still develop over time due

28 to the long turnover time of branched GDGTs. 


\section{INTRODUCTION}

32 Branched glycerol dialkyl glycerol tetraethers (GDGTs) are core membrane lipids synthesised by

33 as yet unknown bacteria (Weijers et al., 2006a). They occur in peat bogs and soils worldwide

34 (Sinninghe Damsté et al., 2000; Leininger et al., 2006; Weijers et al., 2006b; Weijers et al.,

35 2007c; Huguet et al., 2010a; Huguet et al., 2010b). Branched GDGTs consist of two alkyl chains

36 ether bound to two glycerol units. The alkyl moieties contain two or three methyl groups each

37 and in some, one of these methyl groups is incorporated into a cyclopentane moiety likely

38 formed via internal cyclization (Weijers et al., 2006a). It has been shown previously that the

39 relative distribution of the different branched GDGTs relates to soil $\mathrm{pH}$ and temperature (Weijers

40 et al., 2007c; Peterse et al., 2009b; Peterse et al., 2010). The degree of cyclisation of the

41 membrane lipids, expressed in the Cyclisation ratio of Branched Tetraethers (CBT) relates to soil

$42 \mathrm{pH}$, and the degree of methylation, expressed in the Methylation index of Branched Tetraethers

43 (MBT) relates to both soil $\mathrm{pH}$ and temperature. These relationships are explained as adaptations

44 by the GDGT-synthesizing microbe to ambient conditions in order to maintain the cell

45 membrane in a liquid crystalline state, which is necessary to carry out essential cell membrane

46 functions. In soils, the ambient temperature to which branched GDGT-producing bacteria adapt

47 their cell membrane is most certainly soil temperature. As soil temperature data were not

48 available in the global soil dataset studied by Weijers et al. (2007c), a correlation was made

49 between branched GDGT distributions and annual mean air temperature (MAT), under the

50 assumption that soil and air temperature are strongly related to each other and, on a yearly

51 average basis, do not differ substantially from each other. Since these branched GDGTs are

52 preserved in the sedimentary record, this relationship between MBT-CBT and annual MAT

53 could be used as a proxy to reconstruct past temperatures (Weijers et al., 2007c).

After initial application in the Congo deep sea fan to reconstruct past MATs for tropical Africa

56 since the last deglaciation (Weijers et al., 2007a), the MBT-CBT proxy is increasingly being 57 used to reconstruct past MATs. These include, amongst others, deglacial Amazonia (Bendle et 58 al., 2010) and East Asia (Peterse et al., 2011), the middle Pleistocene of southwestern North 59 America (Fawcett et al., 2011), the Miocene of northwestern Europe (Donders et al., 2009), the 60 Eocene-Oligocene boundary for East Greenland (Schouten et al., 2008), the early Eocene of the 
61 Sierra Nevada (Hren et al., 2010) and the Palaeocene-Eocene Thermal Maximum (PETM) in the

62 Arctic (Weijers et al., 2007b). In some cases these palaeotemperature estimates are in agreement 63 with those of other proxies (e.g. Schouten et al., 2008; Ballantyne et al., 2010), however, a 64 potential bias to summer temperatures could not always be excluded. For example, reconstructed 65 MATs for the Arctic at the PETM are high (ca. $25^{\circ} \mathrm{C}$, Weijers et al 2007b) and, although comparable to sea surface temperature estimates, the authors suggested that due to three months of darkness during polar winter these estimates might be biased towards summer temperature. A comparison with much lower MAT estimates obtained from oxygen isotope ratios of biogenic phosphate led Eberle et al. (2010) to suggest that MBT-CBT temperature estimates for the Arctic during the PETM and early Eocene are indeed seasonally biased, i.e. towards the summer. Nevertheless, a recent study by Pucéat et al. (2010) pointed out that, because of methodological biases, it could in fact be the MAT estimate based on these oxygen isotope ratios of biogenic phosphate that might be underestimated by 4 to $8^{\circ} \mathrm{C}$. In addition to these deep time applications, Peterse et al. (2009a) showed for high latitude soils at Svalbard that MBT-CBT temperature estimates were equal to measured annual MAT. However, Rueda et al. (2009) compared MBTCBT derived MAT estimates from a sediment record of the Skagerrak with instrumental temperature data for the last 200 years and found that it best compared with summer temperatures. Thus, there may be a seasonal bias in some MBT-CBT records, although Weijers et al. (2007c) did not find better relationships between MBT-CBT and seasonal temperatures than with annual mean temperatures.

Soil microbial communities are (indirectly) affected by changes in environmental conditions; temperature being one of them (e.g. Frey et al., 2008 and references therein). In a recent study 84 where soils were incubated at elevated temperatures, Feng \& Simpson (2009) observed that, although the biomass and activity of soil microorganisms remained by and large constant, shifts in the overall community composition of microorganisms (i.e., fungi vs. bacteria and gram-

87 negative vs. gram-positive bacteria) might occur as a result of temperature-induced substrate constraints. Similar constraints occur for microbes when temperatures drop below optimum conditions, resulting in limited microbial growth (Nedwell, 1999), and it is generally assumed that microbial activity slows down and shifts to a maintenance-related metabolism when soil

91 freezes. Contrary to this view, however, Harrysson-Drotz et al. (2010) recently reported that both 
92 catabolic and anabolic activities of heterotrophic microorganisms proceeded in frozen boreal

93 forest soil, including the biosynthesis of membrane lipids.

95 It is, therefore, not entirely clear whether the activity of branched-GDGT synthesizing bacteria in 96 soils is dependent on temperature. If this were to be the case, for example via temperature97 induced nutrient input to the soil which may vary according to the growing season of vegetation, 98 this could give rise to a preferential period of prosperity of branched-GDGT synthesizing 99 bacteria. Potentially, this might result in a seasonal bias in the temperature 'recorded' in the 100 membrane lipid composition in the soil. In order to investigate this hypothesis, we analyzed the 101 branched GDGT compositions in one year-long time series from eight different soil plots in 102 Minnesota and Ohio in the U.S.A., in Devon in the U.K. and on the island of Texel in The 103 Netherlands. The sites are all located at mid-latitudes where the seasonal contrasts in temperature 104 and growing season are pronounced. In addition to analyzing branched GDGTs as core lipids 105 (CL), i.e. without polar head groups and representing the fossil pool of GDGTs, we also 106 analyzed, in two soil plots, intact polar lipid (IPL)-derived branched GDGTs, i.e. those with a 107 polar head group and presumably derived from living cells. The results were compared with 108 temperature data from local weather stations as well as with in situ measured soil temperatures.

\section{MATERIALS AND METHODS}

\subsection{Soil Locations and Sampling}

\subsubsection{Itasca State Park and Bath Nature Preserve, United States of America}

116 Six soils were sampled in the United States, three in northwestern Minnesota near Elk Lake in

117 Itasca State Park, Clearwater County, and three in northeastern Ohio near Bath Pond, within 118 Bath Nature Preserve, Summit County. Northwestern Minnesota is characterized by a continental 119 climate with warm, humid summers and very cold winters (Peel et al., 2007). The annual MAT 120 in this part of the state is ca. $4^{\circ} \mathrm{C}$ and annual precipitation ca. $700 \mathrm{~mm}$ (KNMI, 1997). The 121 climate of northeastern Ohio is typical of humid continental regions with hot summers and cold 122 winters (Peel et al., 2007). The annual MAT in this area is ca. $10^{\circ} \mathrm{C}$ and annual precipitation ca. 
$123900 \mathrm{~mm}$ (KNMI, 1997). At both sites, soils with three types of vegetation cover were sampled, 124 i.e. pine, deciduous and open field vegetation. The Itasca State Park soils were sampled from 125 September 2008 until August 2009, and the soils in Bath Nature Preserve from October 2008 126 until September 2009 by colleagues from the University of Akron. Duplicate soil cores were 127 collected at each sampling plot of $3 \times 3 \mathrm{~m}$ using a hand auger or, in case of frozen soil, with 128 hammer and chisel. The $0-5 \mathrm{~cm}$ interval was used for analysis. All soil samples were stored 129 frozen at $-20^{\circ} \mathrm{C}$ in ashed glass jars until further processing. Thermistors (NexSens micro-T 130 temperature loggers) were buried at a depth of ca. $15 \mathrm{~cm}$ in each of the soil plots in Minnesota 131 and Ohio (slightly deeper than the depth interval used for lipid analysis) to record soil

132 temperature 10 times a day (i.e, every $144 \mathrm{~min}$ ). An additional thermistor was set $\sim 1.5 \mathrm{~m}$ above 133 ground level to record ambient air temperatures at the sites. Thermistors recorded temperature 134 approximately every $2.5 \mathrm{~h}$ from September 2008 until October 2009.

\subsubsection{Rowden Moor, United Kingdom}

The time series from the U.K. was obtained from a grassland soil from the long-term 139 experimental research platform site at Rowden Moor near Okehampton (Devon, SW England). 140 Southwestern England is characterized by a humid maritime climate, which means that, in 141 contrast to the U.S.A. soils, seasonal extremes in temperature are smaller and that soil 142 temperature is above freezing point virtually all year round. The annual MAT at this site is $9.6^{\circ} \mathrm{C}$ 143 and the mean annual precipitation is $1056 \mathrm{~mm}$ (Harrod and Hogan, 2008). The soil has a silty 144 clay texture and remains very wet from autumn until early spring due to the virtually 145 impermeable clay layer at $30 \mathrm{~cm}$ depth (Harrod and Hogan, 2008). Samples were taken from the 146 control plot, a gently sloping undrained meadow that receives no fertilizer, although cows graze 147 the meadow for a defined period during the year. The vegetation consists of Lolium perenne with 148 patches of Juncus effuses. The soil was sampled at eighteen time points from November 2008 149 until November 2009. In order to minimize effects caused by the heterogeneous nature of a soil, 150 sampling was performed by taking five $30 \mathrm{~cm}$ long cores with a $3 \mathrm{~cm}$ diameter augur in an $\mathrm{X}$ 151 shape over an area of approximately $30 \times 30 \mathrm{~m}$. The short cores were sliced in $10 \mathrm{~cm}$ depth 152 increments and stored at $-20^{\circ} \mathrm{C}$ until sample processing. Upon freeze drying and removal of the 153 grass cover, the $0-10 \mathrm{~cm}$ interval increments were pooled and powdered using a ball mill and 
154 subsequently extracted. Meteorological data (air temperature, precipitation and soil temperature 155 at $10 \mathrm{~cm}$ depth, all at hourly resolution) were obtained from the on-site official UK MET-Office 156 meteorological station.

\subsubsection{Texel, The Netherlands}

A sandy grassland soil was sampled near the Royal NIOZ on the island of Texel, which is in the northwest of The Netherlands. The Netherlands is, like England, characterized by a maritime climate with wet summers and mild winters. The annual MAT near Texel is $9.4^{\circ} \mathrm{C}$ and mean annual precipitation is $750 \mathrm{~mm}$ (KNMI, 1997). The upper $10 \mathrm{~cm}$ of the soil was sampled

164 monthly from March 2008 until February 2009. Three samples were taken in a triangle shape on 165 a $1 \times 1 \mathrm{~m}$ plot and merged in order to minimize variability due to soil heterogeneity and stored 166 frozen at $-20^{\circ} \mathrm{C}$ until further processing. Upon freeze-drying and grinding, the triplicate samples 167 were pooled. In-situ soil temperatures were measured at the time of sampling (always in the 168 morning) using an Ama-Digit ad $20^{\text {th }}$ digital thermometer. Thus, in contrast with the soil plots 169 from the U.S.A. and the U.K., these soil temperatures do not represent daily averages. Average 170 monthly MATs were obtained from the nearest official weather station at De Kooy, which is 171 located on the mainland ca. $10 \mathrm{~km}$ from Texel (KNMI, 1997).

172

\subsection{Soil Extraction and Fractionation}

175 The soils from Elk Lake watershed and Bath Nature Preserve were processed at the Large Lakes 176 Observatory of the University of Minnesota, Duluth. Soils were freeze-dried and homogenized 177 with mortar and pestle after removal of root clumps and other large pieces of soil debris. Around $17810 \mathrm{~g}$ of soil were solvent extracted using a DIONEX Accelerated Solvent Extractor (ASE) using 179 in $n$-hexane/dichloromethane (DCM) 9:1 (v/v) at $100^{\circ} \mathrm{C}$ and $7.6 \times 10^{6} \mathrm{~Pa}$ to obtain a total lipid 180 extract (TLE). TLE aliquots were evaporated under nitrogen until dry, re-dissolved in $n$ 181 hexane/DCM 9:1 (v/v) and applied to an activated $\mathrm{Al}_{2} \mathrm{O}_{3}$ column. Apolar and polar fractions 182 were eluted with $n$-hexane/DCM 9:1 (v/v) and DCM/methanol (MeOH) 1:1 (v/v), respectively. 
184 The Texel soil was processed at Royal NIOZ, and the Rowden Moor soil at both Rothamsted 185 Research-North Wyke (extraction) and Utrecht University (hydrolysis). For both soils, samples were extracted using a modified Bligh \& Dyer method in order to analyze both IPLs and CLs 187 (Bligh and Dyer, 1959). Freeze dried and powdered soil (ca. $10 \mathrm{~g}$ for the Rowden Moor soil and 188 ca. $3 \mathrm{~g}$ for the Texel soil) was ultrasonically extracted three times for $10 \mathrm{~min}$. using a singlephase solvent mixture of $\mathrm{MeOH} / \mathrm{DCM} /$ phosphate buffer 10:5:4 (v/v/v). Upon centrifugation, supernatants were collected and combined. DCM and phosphate buffer were added to the combined extracts to create a new volume ratio of 5:5:4 (v/v/v) and obtain phase separation. The extract (DCM phase) containing the GDGTs was separated from the residue $(\mathrm{MeOH} / \mathrm{phosphate}$

193 buffer phase) by centrifugation and collected. The residue phase was extracted twice more with 194 DCM and the combined extracts evaporated to near dryness using a rotary evaporator. The extract was passed over a small column plugged with extracted cotton wool to remove any remaining soil particles and then completely dried under a steady stream of pure $\mathrm{N}_{2}$. The extract

197 was subsequently separated into a CL and IPL fraction over a small silica gel column according 198 to Pitcher et al. (Pitcher et al., 2009) with minor modifications. The CL fraction was obtained by 199 eluting with 5 column volumes of $n$-hexane:ethylacetate $1: 1(\mathrm{v} / \mathrm{v})$ and the IPL fraction was 200 obtained by eluting with 5 column volumes of $\mathrm{MeOH}$. A small aliquot of the obtained IPL 201 fraction was analyzed directly using high performance liquid chromatography/mass spectrometry 202 (HPLC/MS) to determine any carryover of CLs into the IPL fraction (see below). In order to 203 analyze IPLs as CLs, the IPL fraction was hydrolyzed to cleave off the polar head groups. To 204 this end the IPL fraction was refluxed for a minimum of $2 \mathrm{~h}$ in $1.5 \mathrm{~N} \mathrm{HCl}$ in $\mathrm{MeOH}$, cooled down 205 and neutralized to $\sim \mathrm{pH}$ 5. To recover the sample, a small amount of double distilled or extracted 206 demineralized water was added and the mixture was extracted three times with DCM, which was 207 subsequently collected and evaporated to dryness. In addition to this acid hydrolysis, an aliquot 208 of the Rowden Moor soil IPL fraction was subjected to base hydrolysis in order to cleave off 209 phosphate bound head groups only. To this end the sample was refluxed for ca. $2 \mathrm{~h}$ in a $1 \mathrm{~N} \mathrm{KOH}$ 210 in $\mathrm{MeOH}: \mathrm{H}_{2} \mathrm{O}$ 95:5 (v/v) mixture, cooled down, neutralized and recovered by extraction with 211 DCM similar as for the acid hydrolysis.

213 All branched GDGTs were quantified against a known amount of a $\mathrm{C}_{46}$ GDGT standard (Huguet 214 et al., 2006) that was added to each fraction. Prior to analysis, the samples were ultrasonically 
215 dissolved in a $n$-hexane:2-propanol 99:1 (v/v) solvent mixture in a concentration of ca $2 \mathrm{mg} / \mathrm{ml}$ 216 and filtered over an $0.45 \mu \mathrm{m}$ PTFE filter (Alltech) to remove any particulates.

\subsection{GDGT Analysis}

All samples were analyzed at Royal NIOZ. GDGTs were analyzed using high performance liquid chromatography - atmospheric pressure chemical ionization / mass spectrometry (HPLCAPCI/MS) on an Agilent 1100 series LC/MSD SL according to Schouten et al. (2007) with minor modifications. Briefly, separation was achieved on an analytical Alltech Prevail Cyano column $(150 \mathrm{~mm} \times 2.1 \mathrm{~mm}, 3 \mathrm{~mm})$. Branched GDGTs were eluted with $90 \% \mathrm{~A}$ and $10 \% \mathrm{~B}$, where $\mathrm{A}=n$-hexane and $\mathrm{B}=n$-hexane:2-propanol 9:1 (v/v), isocratically for the first 5 min (flow rate

$2260.2 \mathrm{ml} \mathrm{min}^{-1}$ ), thereafter with a linear gradient to $18 \% \mathrm{~B}$ in $45 \mathrm{~min}$. Injection volume was $10 \mu \mathrm{l}$

227 for all samples. The different GDGTs were detected by scanning for their $[\mathrm{M}+\mathrm{H}]^{+}$ions 228 (protonated mass) in selected ion monitoring (SIM) mode and the peak area was used for 229 quantification. Absolute quantification was performed according to Huguet et al. (2006). MBT 230 indices and CBT ratios were calculated using peak areas and translated into annual MAT 231 estimates following the soil calibration described in Weijers et al. (2007c).

232 The standard error of estimate of the calibration formula is $5.5^{\circ} \mathrm{C}$. The instrumental 233 reproducibility of the MAT estimate, based on several duplicate HPLC/MS analyses, was \pm $2340.3^{\circ} \mathrm{C}$. The analytical error due to sample processing and analysis was determined by duplicate 235 processing of all Minnesota soil samples and by triplicate processing of four of the Rowden 236 Moor soil samples. For the Minnesota soils, the average standard deviation of the MAT estimates 237 was $1.1^{\circ} \mathrm{C}$ and for the Rowden Moor soil the average standard deviation was $0.4^{\circ} \mathrm{C}$ for the CLs 238 and $1.0^{\circ} \mathrm{C}$ for the IPLs. For the concentration of GDGTs, the analytical error was ca. $25 \%$ for the 239 Minnesota soils and ca. 10\% for the Rowden Moor soil.

\subsection{Correction for Carryover of Core Lipids}

243 As concentrations of IPL-derived branched GDGTs are substantially lower than those of the CL 244 fractions and separation of both fractions over a silica-gel column does not always results in a 245 full separation (likely depending on the extract composition, see Pitcher et al., 2009), small 
246 aliquots of the IPL fraction were analyzed using HPLC/MS without further hydrolysis to screen

247 for the presence of branched GDGT CLs. It appeared that the carryover of CLs into the IPL 248 fraction is minor, i.e. ca. $2 \%$ of all CLs ended up in the IPL fraction, both for Rowden Moor soil 249 and for the Texel soil. However, given the much lower concentrations of GDGTs in the IPL 250 fraction relative to the CL fraction, this pool of leaked CLs accounted for ca. 23\% of all GDGTs measured in the hydrolyzed fraction in Rowden Moor soil and ca. 30\% for the Texel soil.

252 Therefore, the reported concentrations of IPL-derived branched GDGTs were corrected for this.

253 As this (small) fraction of leaked branched GDGT CLs might have a distribution (and thus 254 'temperature signature') that could deviate from the IPL-derived GDGTs, a correction has also 255 been made for the reconstructed MAT based on the IPL-derived GDGTs. This correction was 256 made by subtracting concentrations of individual branched GDGTs of the leaked CL fraction 257 from the concentrations of branched GDGTs in the IPL-derived fraction, and recalculating MAT 258 based on the new distribution. The resulting correction was minimal in the Rowden Moor soil, i.e. $0.4^{\circ} \mathrm{C}$ on average. For the Texel soil this correction is slightly larger, i.e. $1.4^{\circ} \mathrm{C}$ on average.

\section{RESULTS AND DISCUSSION}

\subsection{Instrumental Temperature Data}

All four sites showed clear differences in seasonal air temperature. Due to the maritime climate of western Europe, however, the maximum difference in monthly mean air temperatures at Texel and Rowden Moor, i.e. 16 and $14^{\circ} \mathrm{C}$, respectively, was lower than at the sites in Itasca State Park (Minnesota) and Bath Nature Preserve (Ohio), i.e. 33 and $26^{\circ} \mathrm{C}$, that experience a continental climate (Fig. 1). Daily soil temperatures as measured in the Minnesota, Ohio and Rowden Moor soils showed lower extremes than the measured air temperature due to the heat capacity of soils. Among the Minnesota soils, the pine plot showed slightly lower amplitudes in soil temperature

272 than the open field plot and a delayed response to warming in spring, both most likely as a result 273 of the insulating effect of the vegetation cover. This effect was less pronounced for the Ohio 274 soils. Unfortunately, the thermistor from the deciduous plot in Ohio could not be recovered and 275 the one from the deciduous plot in Minnesota malfunctioned, so we did not obtain in situ temperature data for these soils. Under the assumption that the temperature in the deciduous 
277 forest soil will not deviate substantially from the temperature in the pine forest soil, the latter was 278 used for comparison with the MBT-CBT derived MATs in the deciduous forest soil. For all soils 279 for which in-situ soil temperature data were available, the annual mean soil temperature was 280 higher than the annual MAT (Fig. 1). In the Minnesota and Ohio soils this was mainly due to the 281 fact that winter soil temperatures never reach far below freezing point. For Rowden Moor soil 282 this is principally due to soil temperatures in summer that are about $2^{\circ} \mathrm{C}$ higher than air 283 temperatures, probably due to the insulating effect of the grass cover at night. This difference 284 between mean air and mean soil temperature was smallest in the pine forest soil in Ohio $\left(0.4^{\circ} \mathrm{C}\right)$ 285 and largest in the open field soil from Minnesota $\left(4.4^{\circ} \mathrm{C}\right)$. The difference for the open field 286 grassland at Rowden Moor was $1.3^{\circ} \mathrm{C}$.

\subsection{Branched GDGT Core Lipids}

Concentrations of branched GDGT CLs were determined for all soils and fall within ranges reported in other studies (Kim et al., 2006; Weijers et al., 2006b; Peterse et al., 2009b; Huguet et al., 2010b). For the Minnesota soils, annual averaged concentrations were $240 \pm 60$ (standard deviation) $\mathrm{ng} \mathrm{g}^{-1}$ dry weight soil (dws) for the open field, $290 \pm 70 \mathrm{ng} \mathrm{g}^{-1} \mathrm{dws}$ for the pine forest

294 and $430 \pm 110 \mathrm{ng} \mathrm{g}^{-1} \mathrm{dws}$ for the deciduous forest time series, respectively (Fig. 2a). For the 295 Ohio soils the annual averaged concentrations were $170 \pm 70 \mathrm{ng} \mathrm{g}^{-1} \mathrm{dws}$ for the open field, 2500 $296 \pm 1250 \mathrm{ng} \mathrm{g}^{-1} \mathrm{dws}$ for the pine forest and $310 \pm 170 \mathrm{ng} \mathrm{g}^{-1} \mathrm{dws}$ for the deciduous forest (Fig. 2b). 297 Annual averaged branched GDGT CL concentrations for the Texel and the Rowden Moor

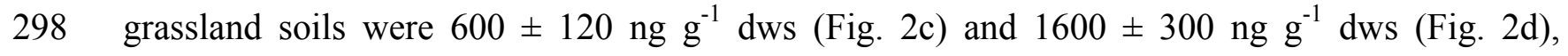
299 respectively. In the Minnesota open field soil, the Ohio soils, the Texel soil and the Rowden 300 Moor soil no seasonal trend in branched GDGT CL concentrations was apparent (Fig. 2). For the 301 Minnesota pine forest and deciduous forest soils somewhat higher concentrations seem to be 302 present in July and August. For the Rowden Moor soil, precipitation data were available, but no 303 relation with precipitation was found.

MBT-CBT reconstructed temperatures (based on the CLs) remained constant throughout the year 306 in all soils, with variations in MAT estimates within the same soil usually $<5^{\circ} \mathrm{C}$ in the 307 Minnesota and Ohio pine forest soils (Figs. 3, 4), $<3^{\circ} \mathrm{C}$ in the deciduous forest and open field 
soils from the same sites (Figs. 3, 4), $<2^{\circ} \mathrm{C}$ in the Texel soil (Fig. 5) and $<1^{\circ} \mathrm{C}$ in the Rowden

309 Moor soil (Fig. 6). The observed variations did not coincide with seasonal variations in soil 310 temperature. The average MBT-CBT derived temperatures for the Minnesota soils were $10.3^{\circ} \mathrm{C}$ $311 \pm 1.2^{\circ} \mathrm{C}$ (standard deviation) for the open field site and $9.9^{\circ} \mathrm{C} \pm 1.9^{\circ} \mathrm{C}$ for the pine site, which are 312 clearly warmer than the annual MAT of $3.8^{\circ} \mathrm{C}$ but closer to the annual mean soil temperature of $3138.2^{\circ} \mathrm{C}$ at the open field site and $6.0^{\circ} \mathrm{C}$ at the pine site (Fig. 1). For the Ohio soils, the average 314 MBT-CBT derived temperatures were $8.4^{\circ} \mathrm{C} \pm 0.9^{\circ} \mathrm{C}$ for the open field and $12.6^{\circ} \mathrm{C} \pm 1.6^{\circ} \mathrm{C}$ for 315 the pine plot, which are both close to the annual MAT of $9.9^{\circ} \mathrm{C}$ and the measured annual mean 316 soil temperature of $10.4^{\circ} \mathrm{C}$ at the open field site and $10.0^{\circ} \mathrm{C}$ at the pine site (Fig. 1). Strikingly, 317 MBT-CBT reconstructed temperatures for the deciduous soils in both Minnesota and Ohio were 318 high, i.e. $14.0^{\circ} \mathrm{C} \pm 0.9^{\circ} \mathrm{C}$ and $19.2^{\circ} \mathrm{C} \pm 1.0^{\circ} \mathrm{C}$, respectively (Figs. 3, 4). This is 10.2 and $9.6^{\circ} \mathrm{C}$, 319 respectively, higher than measured annual MAT and 8.0 and $9.2^{\circ} \mathrm{C}$, respectively, higher than 320 annual mean soil temperature under pine forest (Fig. 1). Unfortunately, no soil temperature data 321 were available for both deciduous plots, but it seems unlikely that these would be that much 322 higher than under pine forest. This makes these soils the only two in this set of eight to give 323 reconstructed MATs that show offsets to measured temperature larger than the standard error of 324 estimate of the soil calibration dataset of ca. $5.5^{\circ} \mathrm{C}$ (Weijers et al., 2007b). The reason for this 325 deviating pattern is, at present, not clear. For the Texel soil, the MBT-CBT reconstructed temperature based on the CLs was $7.1^{\circ} \mathrm{C} \pm 0.8^{\circ} \mathrm{C}$, which is slightly lower than the annual MAT 327 for this area of $9.4^{\circ} \mathrm{C}$ (Fig. 1, 5). Of the eight soils sampled, the reconstructed temperature based 328 on CLs in the Rowden Moor soil was the most stable throughout the year at $11.1^{\circ} \mathrm{C} \pm 0.7^{\circ} \mathrm{C}$, which is close to annual MAT of $9.6^{\circ} \mathrm{C}$ and equal to the annual mean soil temperature of $11.1^{\circ} \mathrm{C}$ 330 (Fig. 2, 6). One exception is the sample from May $15^{\text {th }}$ that gave a reconstructed temperature of $3319^{\circ} \mathrm{C}$. This is clearly lower than the reconstructed temperature for the sample taken a week earlier

332 (May $7^{\text {th }} ; 11.2^{\circ} \mathrm{C}$ ) and that of June $4^{\text {th }}\left(11.6^{\circ} \mathrm{C}\right)$. This particular sample is also an outlier in terms 333 of the concentration of branched GDGTs.

335 In all soils for which continuous soil temperature data are available, i.e. Minnesota open field 336 and pine forest, Ohio open field and pine forest and Rowden Moor soil, the MBT-CBT 337 reconstructed temperature was closer to the measured annual mean soil temperature than to the 338 measured annual MAT. This is surprising as in the soil calibration dataset a calibration was made 
with annual MAT and not with soil temperature (Weijers et al., 2007c). As is also evident from

340 the temperature data shown here, soil and air temperature are not identical, and more 341 importantly, the offset differs with region and type of vegetation. The observed variation 342 depends on a range of factors, including differences in vegetation cover, water content (which 343 determines heat capacity) and latitude (intensity of winter frost conditions) of the soil (e.g. Oliver 344 et al., 1987). The fact that MBT-CBT reconstructed temperatures do not always exactly reflect 345 annual MAT implies that, as suggested by Weijers et al. (2007c), a substantial part of the scatter 346 present in the MBT-CBT calibration may result from this variation in the offset between soil and 347 air temperatures.

The branched GDGT CL assemblages in the eight soils analyzed, clearly showed no response to seasonal changes in temperature. This lack of any seasonal trend may be ascribed to a standing stock of CLs whose abundance is much larger than new production of branched GDGTs over a seasonal cycle. Earlier work, comparing the amount of branched GDGT CLs in a peat core with 353 cell numbers of the most dominant bacteria, suggested the presence of such a standing stock of 354 CLs (Weijers et al., 2009). Indeed, Weijers et al. (2010) showed by means of the stable carbon isotopic composition of the branched alkanes released from branched GDGTs that their turnover 356 time, at least in mid-latitude cropland soils, is near 20 years, and Peterse et al. (2010) showed that the branched GDGT (CLs) composition in a grassland soil had fully adjusted to a manipulated change in $\mathrm{pH}$ after 40 years. These studies indicate that the standing stock of branched GDGT CLs turns over on timescales of decades and that, consequently, the distribution of branched GDGT CLs in a given soil is adjusted to new environmental conditions at these time scales. This turnover time of decades for branched GDGT CLs also implies that the variation in

362 CL concentration as found in some soils has to be interpreted with care. It seems unlikely that the 363 pool of CLs is suddenly halved or doubled in a month. These variations are likely to be, at least 364 partly, the result of the well-known spatial heterogeneity of soils. From the work presented here, 365 it is clear that the branched GDGT CL distribution does not adjust to changes in ambient 366 conditions (at least temperature) on time scales $<1$ year. The turnover time of near 20 years 367 implies that the MAT signal documented by the branched GDGT CLs is a time-integrated signal 368 over previous years (with the potential for a greater weighting for more recent years, though this 
remains to be demonstrated).

\subsubsection{Acid-hydrolyzed IPLs}

Since branched GDGT CL distributions did not show a response to seasonal variations, we analyzed IPL-derived branched GDGTs which are presumably a better reflection of the extant soil bacterial population. Therefore, for the Texel soil and Rowden Moor soil, IPL branched GDGTs were separated from the CLs, hydrolyzed and analyzed as CLs. Concentrations of these IPL-derived branched GDGTs varied from ca. $40 \pm 15 \mathrm{ng} \mathrm{g}^{-1} \mathrm{dws}$ in the Texel soil (Fig. 2c) to ca. $150 \pm 30 \mathrm{ng} \mathrm{g}^{-1} \mathrm{dws}$ in the Rowden Moor soil (Fig. 2d). However, as observed for the CLs, no relationship was apparent between the concentration of the IPL-derived branched GDGTs and temperature (Figs. 2, 5,6). The IPL fraction of the branched GDGTs in the soils only accounted for 6\% (Texel soil) and 9\% (Rowden Moor soil) of the total branched GDGT pool, which is only slightly higher than the value of $4 \%$ reported by Liu et al. (2010) in a German peat bog. Assuming that all IPLs are derived from extant biomass, this indicates that more than $90 \%$ of the branched GDGTs present in the soil are in a fossil (CL) form.

Although temperature estimates reconstructed using branched GDGTs from the IPL fraction were expected to better reflect seasonal temperature, this is not the case. In the Texel soil, temperature reconstructions based on the IPL-derived branched GDGTs showed values that are similar to the estimates based on the $\mathrm{CL}$ fraction (Fig. 5; average $6.7^{\circ} \mathrm{C} \pm 1.0^{\circ} \mathrm{C}$ ). Except for 393 i.e. within analytical error. In the Rowden Moor soil, temperature estimates based on GDGTs 394 from the IPL (acid-hydrolyzed) fraction differed slightly more from the estimates based on the $395 \mathrm{CL}$ fraction (Fig. 6; average $10.6^{\circ} \mathrm{C} \pm 2.2^{\circ} \mathrm{C}$ ). IPL based temperature estimates were either up to $3962.4{ }^{\circ} \mathrm{C}$ higher (September) or down to $3.4^{\circ} \mathrm{C}$ lower (February) than the CL based estimates of the 397 same months. Although these two extremes might suggest some kind of adaptation, it has to be 398 noted that higher IPL-based than CL-based temperature estimates also occurred in winter and 399 lower estimates in summer. A Student's t-test shows that IPL-derived MAT estimates for the 
warm part of the year (in this case defined as May - October) were not significantly higher than

401 CL-derived MAT estimates, and that IPL-derived MAT estimates for the cool part of the year

402 (November - April) were only just significantly lower than CL-derived MAT estimates, in both

403 cases at a 95\% confidence interval. This indicates that the data indeed are scattered and that there

404 is no unambiguous clear trend in IPL-derived MAT related to seasonal changes in temperature

405 (Fig. 6).

407 These results suggest that, as with the CL branched GDGTs, the turnover of IPL-derived 408 branched GDGTs in soil is rather slow, albeit perhaps faster than for CL branched GDGTs. One 409 potential cause for this would be if IPLs are also preserved over time scales of months to years, 410 as this would result in a smoothing of the seasonal temperature signal. Harvey et al. (1986) 411 observed that bacterial phospholipids degrade relatively fast, whereas glycosidically bound ether 412 lipids degrade much more slowly. Based on modeling of degradation rates in the marine 413 environment, Schouten et al. (2010) recently proposed that a significant portion of glycosidic 414 GDGTs could indeed be preserved in the sedimentary record. Liu et al. (2010) recently reported 415 the occurrence of branched GDGT IPLs containing glycosidic head groups in a German peat 416 bog, but no IPLs containing a phospho head group, suggesting that glycosidic branched GDGT 417 IPLs may indeed be preserved over time scales longer than those of phospho IPLs.

\subsubsection{Base-hydrolyzed IPLs}

421 To investigate whether the majority of the branched GDGT IPL pool consisted of glycolipids, an 422 aliquot of the IPL fraction of the Rowden Moor soil samples was subjected to base hydrolysis, 423 which only cleaves ester bound phospho head groups and not ether bound glycosidic head 424 groups. The average concentration of the phospho IPL-derived branched GDGTs was ca. $110 \pm$ $42530 \mathrm{ng} \mathrm{g}^{-1}$ dws (Fig. 2d). Comparison with the yield of the acid-hydrolyzed IPL aliquot, which 426 was ca. $150 \mathrm{ng} \mathrm{g}^{-1} \mathrm{dws}$ and represents the sum of phospho IPLs and glycosidic IPLs, suggests 427 that the majority of the branched GDGT IPLs contain ester bound phosphate head groups. Given 428 that glycosidic branched GDGTs might even be enriched in abundance over time relative to the 429 phospho IPLs due to their supposedly slower degradation rate, this suggests that the amount of 430 glycolipids produced by the branched-GDGT synthesizing bacteria is small relative to the 
431 phospholipids. This is in apparent contradiction with the work of Liu et al. (2010) who only 432 found glycosidic head groups for the branched GDGTs, although it needs to be stressed that this 433 was in a peat bog rather than a soil.

435 If the branched GDGTs released upon base hydrolysis are derived from (more labile) 436 phospholipid branched GDGTs, then they may be a better reflection of the living bacterial 437 population. However, also in the base-hydrolyzed fraction, GDGT concentrations showed no 438 relationship with temperature over the seasons (Fig. 6). The MBT-CBT reconstructed MAT 439 based on the base-hydrolyzed IPL fraction (average $10.7^{\circ} \mathrm{C} \pm 2.1^{\circ} \mathrm{C}$ ) also showed no noticeable 440 difference with temperatures reconstructed for the acid-hydrolyzed fraction or the CL fraction 441 (Fig. 6). Except for June $\left(-1.2^{\circ} \mathrm{C}\right)$, the differences between reconstructed MATs in the acid- and 442 base-hydrolyzed samples were within $1{ }^{\circ} \mathrm{C}$, and thus within analytical uncertainty. In fact, this 443 similarity is not strange given that the majority of IPLs seems to consist of phospho bound IPLs, 444 which are measured in both the acid- and the base-hydrolyzed fraction. Thus, the small 445 differences in estimated MAT over the course of a year, based on the acid-hydrolysed IPL 446 fractions both in the Texel soil and in the Rowden Moor soil, is likely not due to the specific 447 presence of larger amounts of preserved glycosidic IPLs.

449 Assuming then that IPL-derived branched GDGTs represent living biomass, it might be that 450 branched-GDGT synthesizing bacteria have low cell division rates and exhibit relatively long 451 regeneration times. This would have a similar smoothing effect as with fossil GDGTs in the CL 452 fraction, since part of the IPLs detected at a given point in time could be produced several 453 months earlier. Indeed, many bacteria are known to grow slowly. An extreme example are the 454 anammox bacteria with cell division times up to a month (Van de Graaf et al., 1996; Strous et al., 455 1998). Also several Acidobacteria, the bacterial phylum potentially containing the branched456 GDGT synthesizing bacteria (Weijers et al., 2009), are relatively slow growers (Eichorst et al., 457 2007; Davis et al., 2011). Given that there is no systematic variation over the year in the MBT458 CBT reconstructed temperatures for the IPL-derived branched GDGTs, the combined effects of 459 suspected slow regeneration times of the responsible bacteria and the slow degradation rate of 460 IPLs suggest a perceived turnover time of IPLs in these soils in the order of a year. 


\section{IMPLICATIONS}

464 Previous studies have shown that branched GDGT-synthesizing soil microbes adapt their 465 membrane lipid distributions to $\mathrm{pH}$ and temperature (Weijers et al., 2007c; Peterse et al., 2009b; 466 Peterse et al., 2010). These are the ambient $\mathrm{pH}$ and temperature and thus soil $\mathrm{pH}$ and soil 467 temperature. Since for the global soil calibration dataset no soil temperature data were available, 468 a calibration was made with annual MAT under the assumption that the two are roughly equal. 469 Although on larger regional and global scales this will be true, on a local scale, as is evident from our study, soil and air temperature are not equal, and more importantly, also the offset between the two is not the same everywhere. It is important to realize, therefore, that, as also indicated by

472 Weijers et al. (2007c), a large part of the scatter in the MBT-CBT calibration with annual MAT 473 (which gives a standard error of estimate of ca. $5^{\circ} \mathrm{C}$ ) may result from this offset between soil and 474 air temperature. As a consequence, absolute temperatures reconstructed with the MBT-CBT 475 proxy, though calibrated with annual MAT, do not always exactly reflect annual MAT, like in 476 some of the soils studied here. On the larger scale, nevertheless, the MBT-CBT proxy is still 477 thought to be able to provide reasonable estimates of past annual MAT and, especially, of 478 changes therein (e.g. Weijers et al., 2007a). It is the reconstructed absolute temperature that is 479 associated with a slightly larger error (ca. $5^{\circ} \mathrm{C}$ ). This could only be better constrained when pure 480 cultures of the branched-GDGT synthesizing bacteria are available or when studies like the 481 current one, where soil temperatures are monitored over the annual cycle, are performed on a 482 wide variety of soils.

484 Our study clearly shows that in mid-latitude soils, no seasonal trends are apparent in the 485 concentration and distribution of branched GDGT CLs. Also in IPL-derived branched GDGT 486 concentration and distribution no clear seasonal trends are apparent. Thus, from the data 487 presented here, it seems that palaeoclimate reconstructions based on branched GDGT CL 488 distributions do not suffer from particular seasonal biases. However, we cannot fully exclude the 489 hypothesis that production of GDGTs in a certain season could be slightly higher than in others, 490 but that these monthly differences are obscured as they are very small relative to the standing 491 stock of GDGTs. A turnover time of 20 years for CLs implies that ca. 5\% of the pool is refreshed 492 in a given year, or ca. $0.4 \%$ per month. Monthly variations in this small percentage will not be 
493 detectable. Similarly, for the IPL-derived GDGT pool small variations in its turnover rate of ca.

$4948 \%$ per month (based on an assumed turnover time in the order of a year), will likely be obscured

495 by variability due to the heterogeneity of soils. Over the course of 20 years, these small seasonal

496 biases might influence the long term average distribution of branched GDGT CLs and thus the

497 temperature reconstructed using the MBT-CBT proxy. This effect might be expected to be

498 stronger in soils experiencing stronger contrasts between seasons. If such an offset exists, it is,

499 however, not necessarily directed towards a particular season, given that the Texel soil, or the

500 Ohio open field soil, for example, gave reconstructed temperatures lower than annual MAT

501 while the Minnesota soils give reconstructed temperature higher than annual MAT.

502

503 The results presented here are derived from soils from mid-latitudes. In the tropics, seasonal

504 contrasts in temperature are much smaller and seasonal biases in MBT-CBT reconstructed MATs

505 are, therefore, expected to be much less of an issue in these climates. Our study, however, cannot

506 completely rule out the presence of a seasonal bias at high latitude sites like the Arctic, as a

507 period of up to three months of darkness may have, indirectly via vegetation and nutrient flows,

508 substantial effects on the soil microbial communities. For present-day Svalbard, nevertheless,

509 reconstructed MAT based on branched GDGT CL distributions is close to measured annual

510 MAT (i.e. $-4^{\circ} \mathrm{C}$ and $-6^{\circ} \mathrm{C}$, respectively, Peterse et al., 2009a).

512 The fact that branched GDGT CLs represent a standing stock that has accumulated over the 513 course of years (ca. 20 years, Weijers et al., 2010) not only explains why the MBT-CBT proxy in 514 soils relates with an annual average temperature, it also implies that the proxy can only be 515 applied on geological time scales with resolutions larger than several decades. Most applications 516 that used the MBT-CBT proxy in obtaining records of MAT estimates have been obtained from 517 sites receiving fluvial transported sediments and are, therefore, already considerably temporally 518 smoothed (e.g. Weijers et al., 2007a), but this issue could be important in cases where the proxy 519 is used in high resolution studies of peat or loess deposits. 
Acknowledgements. Dr. L. Schwark and two anonymous reviewers are acknowledged for

524 providing helpful comments that have improved the earlier version of our manuscript. This study was made possible by financial support from the Netherlands Organisation for Scientific 526 Research (NWO) through a VENI grant to J.W.H.W.. The European Science Foundation is 527 thanked for providing an ESF-MOLTER Short Visit Grant to J.W.H.W. that enabled a stay at 528 Rothamsted Research - North Wyke. F.P., S.S. and J.S.D. thank the Darwin Center for 529 Biogeosciences and the Royal NIOZ for funding. S.S. and J.S.D. received funding from the ERC 530 project PACEMAKER. J.P.W. received funding from the US National Science Foundation grant 531 EAR-0745658 and acknowledges support from the Gledden Fellowship. This work forms 532 contribution 2400-JW at the Centre for Water Research, The University of Western Australia. 533 Matt Kemp and Lisa Park from the University of Akron are gratefully acknowledged for sampling assistance.

Ballantyne A. P., Greenwood D. R., Sinninghe Damsté J. S., Csank A. Z., Eberle J. J., and Rybczynski N. (2010) Significantly warmer Arctic surface temperatures during the Pliocene indicated by multiple independent proxies. Geology 38, 603-606.

Bendle J. A., Weijers J. W. H., Maslin M. A., Sinninghe Damsté J. S., Schouten S., Hopmans E. C., Boot C. S., and Pancost R. D. (2010) Major changes in glacial and Holocene terrestrial temperatures and sources of organic carbon recorded in the Amazon fan by tetraether lipids. Geochem. Geophys. Geosyst. 11, 1-13, Q12007, doi:10.1029/2010GC003308.

Bligh E. G. and Dyer W. J. (1959) A rapid method of total lipid extraction and purification. Can. J. Biochem. Physiol. 37, 911-917.

Davis K. E. R., Sangwan P., and Janssen P. H. (2011) Acidobacteria, Rubrobacteridae and Chloroflexi are abundant among very slow-growing and mini-colony-forming soil bacteria. Environ. Microbiol. in press, doi:10.1111/j.1462-2920.2010.02384.x.

Donders T. H., Weijers J. W. H., Munsterman D. K., Hoeve M. L. K. V., Buckles L. K., Pancost R. D., Schouten S., Sinninghe Damsté J. S., and Brinkhuis H. (2009) Strong climate coupling of terrestrial and marine environments in the Miocene of northwest Europe. Earth Planet. Sci. Lett. 281, 215-225. 
Drotz S. H., Sparrman T., Nilsson M. B., Schleucher J., and Oquist M. G. (2010) Both catabolic and anabolic heterotrophic microbial activity proceed in frozen soils. Proc. Natl. Acad. Sci. USA 107, 21046-21051.

Eberle J. J., Fricke H. C., Humphrey J. D., Hackett L., Newbrey M. G., and Hutchison J. H. (2010) Seasonal variability in Arctic temperatures during early Eocene time. Earth Planet. Sci. Lett. 296, 481-486.

Eichorst S. A., Breznak J. A., and Schmidt T. M. (2007) Isolation and characterization of soil bacteria that define Teniglobus gen. nov., in the phylum Acidobacteria. Appl. Environ. Microbiol. 73, 2708-2717.

Fawcett P., Werne J.P., Anderson R., Heikoop J., Brown E., Berke M., Smith S., Goff F., Hurley L., Cisneros-Dozal M., Schouten S., Sinninghe Damsté J.S., Huang Y., Toney J., Fessenden J., WoldeGabriel G., Atudorei V., Geissman J., Allen C. (2011) Extended megadroughts in the southwestern United States during Pleistocene interglacials. Nature. In press. DOI:10.1038/nature09839.

Feng X. J. and Simpson M. J. (2009) Temperature and substrate controls on microbial phospholipid fatty acid composition during incubation of grassland soils contrasting in organic matter quality. Soil Biol. Biochem. 41, 804-812.

Frey S. D., Drijber R., Smith H., and Melillo J. (2008) Microbial biomass, functional capacity, and community structure after 12 years of soil warming. Soil Biol. Biochem. 40, 2904-2907.

Harrod T. R. and Hogan D. V. (2008) The soils of North Wyke and Rowden. Online available at http://www.northwyke.bbsrc.ac.uk/assets/pdf_files/Soils\%20of\%20NW\%20\%20Rowden\%20 2.pdf.

Harvey H. R., Fallon R. D., and Patton J. S. (1986) The effect of organic matter and oxygen on the degradation of bacterial membrane lipids in marine sediments. Geochim. Cosmochim. Acta 50, 795-804.

Hren M. T., Pagani M., Erwin D.M., and Brandon M. (2010) Biomarker reconstruction of the early Eocene paleotopography and paleoclimate of the northern Sierra Nevada. Geology 38, 710.

Huguet A., Fosse C., Laggoun-Defarge F., Toussaint M. L., and Derenne S. (2010a) Occurrence and distribution of glycerol dialkyl glycerol tetraethers in a French peat bog. Org. Geochem. 41, 559-572.

Huguet A., Fosse C., Metzger P., Fritsch E., and Derenne S. (2010b) Occurrence and distribution of extractable glycerol dialkyl glycerol tetraethers in podzols. Org. Geochem. 41, 291-301.

Huguet C., Hopmans E. C., Febo-Ayala W., Thompson D. H., Sinninghe Damsté J. S., and Schouten S. (2006) An improved method to determine the absolute abundance of glycerol dibiphytanyl glycerol tetraether lipids. Org. Geochem. 37, 1036-1041. 
Kim J.-H., Schouten S., Buscail R., Ludwig W., Bonnin J., Sinninghe Damsté J. S., and Bourrin F. (2006) Origin and distribution of terrestrial organic matter in the NW Mediterranean (Gulf of Lion): application of the newly developed BIT index. Geochem. Geophys. Geosyst. 7, Q11017, doi:10.1029/2006GC001306.

KNMI (1997) World Climate Information (WKI) 2.0. Online available at: http://www.knmi.nl/klimatologie/normalen1971-2000/wki.html, Koninklijk Nederlands Meteorologisch Instituut (KNMI), De Bilt, The Netherlands.

Leininger S., Urich T., Schloter M., Schwark L., Qi J., Nicol G. W., Prosser J. I., Schuster S. C., and Schleper C. (2006) Archaea predominate among ammonia-oxidizing prokaryotes in soils. Nature 442, 806-809.

Liu X.-L., Leider A., Gillespie A., Gröger J., Versteegh G. J. M., and Hinrichs K.-U. (2010) Identification of polar lipid precursors of the ubiquitous branched GDGT orphan lipids in a peat bog in Northern Germany. Org. Geochem. 41, 653-660.

Nedwell D. B. (1999) Effect of low temperature on microbial growth: lowered affinity for substrates limits growth at low temperature. FEMS Microbiol. Ecol. 30, 101-111.

Oliver S. A., Oliver H. R., Wallace J. S., and Roberts A. M. (1987) Soil heat-flux and temperature-variation with vegetation, soil type and climate. Agricult. Forest Meteorol. 39, 257-269.

Peel M. C., Finlayson B. L., and McMahon T. A. (2007) Updated world map of the KoppenGeiger climate classification. Hydrol. Earth Syst. Sci. 11, 1633-1644.

Peterse F., Kim J.-H., Schouten S., Klitgaard Kristensen D., Koç N., and Sinninghe Damsté J. S. (2009a) Constraints on the application of the MBT/CBT palaeothermometer at high latitude environments (Svalbard, Norway). Org. Geochem. 40, 692-699.

Peterse F., Nicol G. W., Schouten S., and Sinninghe Damsté J. S. (2010) Influence of soil pH on the abundance and distribution of core and intact polar lipid-derived branched GDGTs in soil. Org. Geochem. 41, 1171-1175.

Peterse F., Prins M. A., Beets C. J., Troelstra S. R., Zheng H., Gu Z., Schouten S., and Sinninghe Damsté J. S. (2011) Decoupled warming and monsoon precipitation in East Asia over the last deglaciation. Earth Planet. Sci. Lett. 301, 256-264.

Peterse F., Schouten S., van der Meer J., van der Meer M. T. J., and Sinninghe Damsté J. S. (2009b) Distribution of branched tetraether membrane lipids in geothermally heated soils: implications for the MBT/CBT temperature proxy. Org. Geochem. 40, 201-205.

Pitcher A., Hopmans E. C., Schouten S., and Sinninghe Damsté J. S. (2009) Separation of core and intact polar archaeal tetraether lipids using silica columns: Insights into living and fossil biomass contributions. Org. Geochem. 40, 12-19. 
Rueda G., Rosell-Melé A., Escala M., Gyllencreutz R., and Backman J. (2009) Comparison of instrumental and GDGT-based estimates of sea surface and air temperatures from the Skagerrak. Org. Geochem. 40, 287-291.

Schouten S., Eldrett J., Greenwood D. R., Harding I., Baas M., and Sinninghe Damsté J. S. (2008) Onset of long-term cooling of Greenland near the Eocene-Oligocene boundary as revealed by branched tetraether lipids. Geology 36, 147-150.

Schouten S., Huguet C., Hopmans E. C., Kienhuis M. V. M., and Sinninghe Damsté J. S. (2007) Analytical methodology for TEX86 paleothermometry by high-performance liquid chromatography/atmospheric pressure chemical ionization-mass spectrometry. Anal. Chem. 79, 2940-2944.

Schouten S., Middelburg J. J., Hopmans E. C., and Sinninghe Damsté J. S. (2010) Fossilization and degradation of intact polar lipids in deep subsurface sediments: A theoretical approach. Geochim. Cosmochim. Acta 74, 3806-3814.

Sinninghe Damsté J. S., Hopmans E. C., Pancost R. D., Schouten S., and Geenevasen J. A. J. (2000) Newly discovered non-isoprenoid glycerol dialkyl glycerol tetraether lipids in sediments. Chem. Commun. 1683-1684.

Strous M., Heijnen J. J., Kuenen J. G., and Jetten M. S. M. (1998) The sequencing batch reactor as a powerful tool for the study of slowly growing anaerobic ammonium-oxidizing microorganisms. Appl. Microbiol. Biotechnol. 50, 589-596.

Van de Graaf A. A., de Bruijn P., Robertson L. A., Jetten M. S. M., and Kuenen J. G. (1996) Autotrophic growth of anaerobic ammonium-oxidizing micro-organisms in a fluidized bed reactor. Microbiology-UK 142, 2187-2196.

Weijers J. W. H., Panoto E., Van Bleijswijk J., Schouten S., Rijpstra W. I. C., Balk M., Stams A. J. M., and Sinninghe Damsté J. S. (2009) Constraints on the biological source(s) of the orphan branched tetraether membrane lipids. Geomicrobiol. J. 26, 402-414.

Weijers J. W. H., Schefuß E., Schouten S., and Sinninghe Damsté J. S. (2007a) Coupled thermal and hydrological evolution of tropical Africa over the last deglaciation. Science 315, 17011704.

Weijers J. W. H., Schouten S., Hopmans E. C., Geenevasen J. A. J., David O. R. P., Coleman J. M., Pancost R. D., and Sinninghe Damsté J. S. (2006a) Membrane lipids of mesophilic anaerobic bacteria thriving in peats have typical archaeal traits. Environ. Microbiol. 8, 648657.

Weijers J. W. H., Schouten S., Sluijs A., Brinkhuis H., and Sinninghe Damsté J. S. (2007b) Warm Arctic continents during the Palaeocene-Eocene thermal maximum. Earth Planet. Sci. Lett. 261, 230-238. 
662 Weijers J. W. H., Schouten S., Spaargaren O. C., and Sinninghe Damsté J. S. (2006b)

663 Occurrence and distribution of tetraether membrane lipids in soils: Implications for the use of 664 the TEX 86 proxy and the BIT index. Org. Geochem. 37, 1680-1693.

665 Weijers J. W. H., Schouten S., van den Donker J. C., Hopmans E. C., and Sinninghe Damsté J. S. 666 (2007c) Environmental controls on bacterial tetraether membrane lipid distribution in soils. 667 Geochim. Cosmochim. Acta 71, 703-713.

668 Weijers J. W. H., Wiesenberg G. L. B., Bol R., Hopmans E. C., and Pancost R. D. (2010) Carbon 669 isotopic composition of branched tetraether membrane lipids in soils suggest a rapid turnover 670 and a heterotrophic life style of their source organism(s). Biogeosciences 7, 2959-2973.

671

672

673

674

675

676

677

678 


\section{Figure captions}

Fig.1: Overview of reconstructed annual mean air temperatures using the MBT-CBT proxy

Fig. 2: Concentrations of branched GDGTs over the one-year time series analyzed in the different soils. A) core lipids (CLs) in the soils at Itasca State Park, Minnesota, USA; B) CLs in the soils at Bath Nature Preserve, Ohio, USA; C) CLs and intact polar lipid (IPL)derived branched GDGTs in the grassland soil at Texel, The Netherlands; and D) CLs, total IPL-derived branched GDGTs and branched GDGTs derived from phosphate-bound IPLs in the grassland soil from Rowden Moor, UK.

Fig. 3: MBT-CBT reconstructed MATs (dots) for A) the open field soil; B) the pine forest soil; and C) the deciduous forest soil at Itasca State Park, Minnesota, USA, plotted against the daily mean air temperature (grey line) and daily mean soil temperature at $15 \mathrm{~cm}$ depth (black line). The horizontal grey striped line represents the measured annual MAT and the horizontal black striped line the measured annual mean soil temperature at the site. Note that the soil temperature curve in graph $\mathrm{C}$ is actually the soil temperature measured in the pine forest soil (see text).

Fig. 4: MBT-CBT reconstructed MATs (dots) for A) the open field soil; B) the pine forest soil; and C) the deciduous forest soil at Bath Nature Preserve, Ohio, USA, plotted against the daily mean air temperature (grey line) and daily mean soil temperature at $15 \mathrm{~cm}$ depth 
(black line). The horizontal grey striped line represents the measured annual MAT and the horizontal black striped line the measured annual mean soil temperature at the site. Note that the soil temperature curve in graph $\mathrm{C}$ is actually the soil temperature measured in the pine forest soil (see text).

715 Fig. 5: MBT-CBT reconstructed MATs based on core lipid (CL, black circles) and intact polar lipid (IPL, white squares)-derived branched GDGTs, for the grassland soil at Texel, The Netherlands, plotted against monthly mean air temperature (black line) and the measured soil temperature at $10 \mathrm{~cm}$ depth at the time of sampling (black crosses).

Fig. 6: MBT-CBT reconstructed MATs based on branched GDGT core lipids (CL, black circles), IPL-derived branched GDGTs after acid hydrolysis (white squares) and IPLderived branched GDGTs after base hydrolysis (white diamonds), for the grassland soil at Rowden Moor, UK, plotted against measured daily mean air temperature (grey line) and measured daily mean soil temperature at $10 \mathrm{~cm}$ depth (black line). 
Figure 1

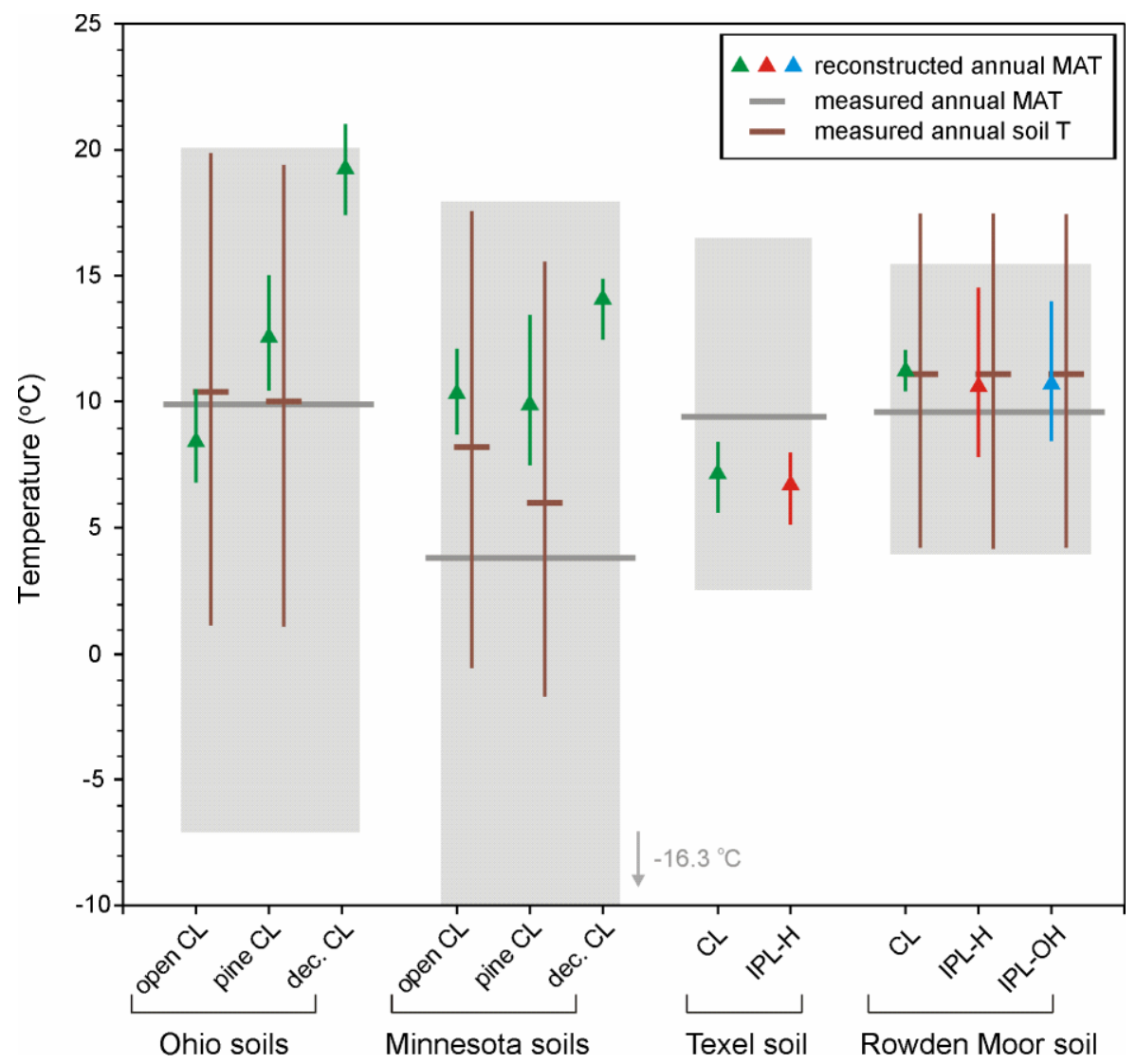


Figure 2
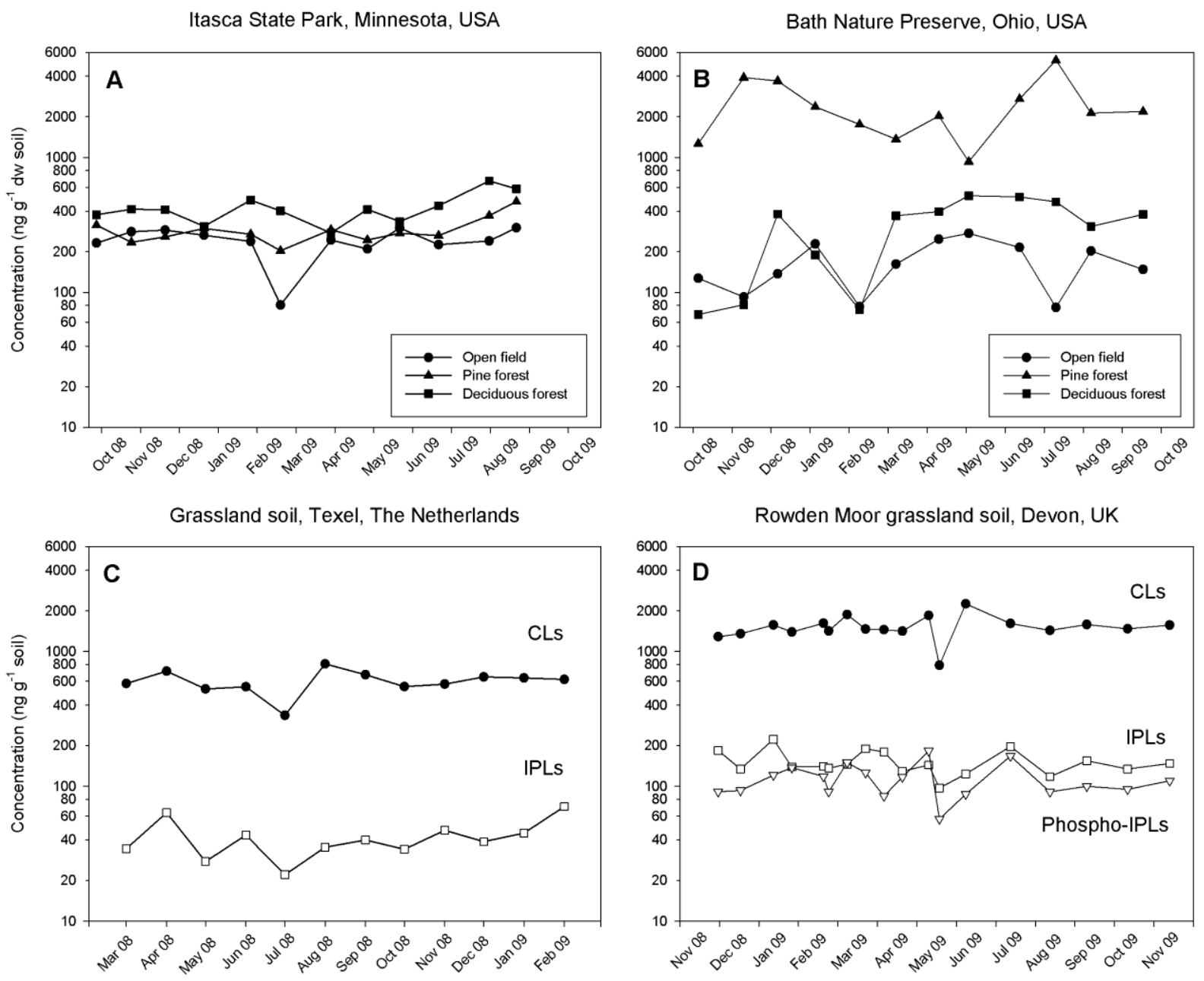
Figure 3
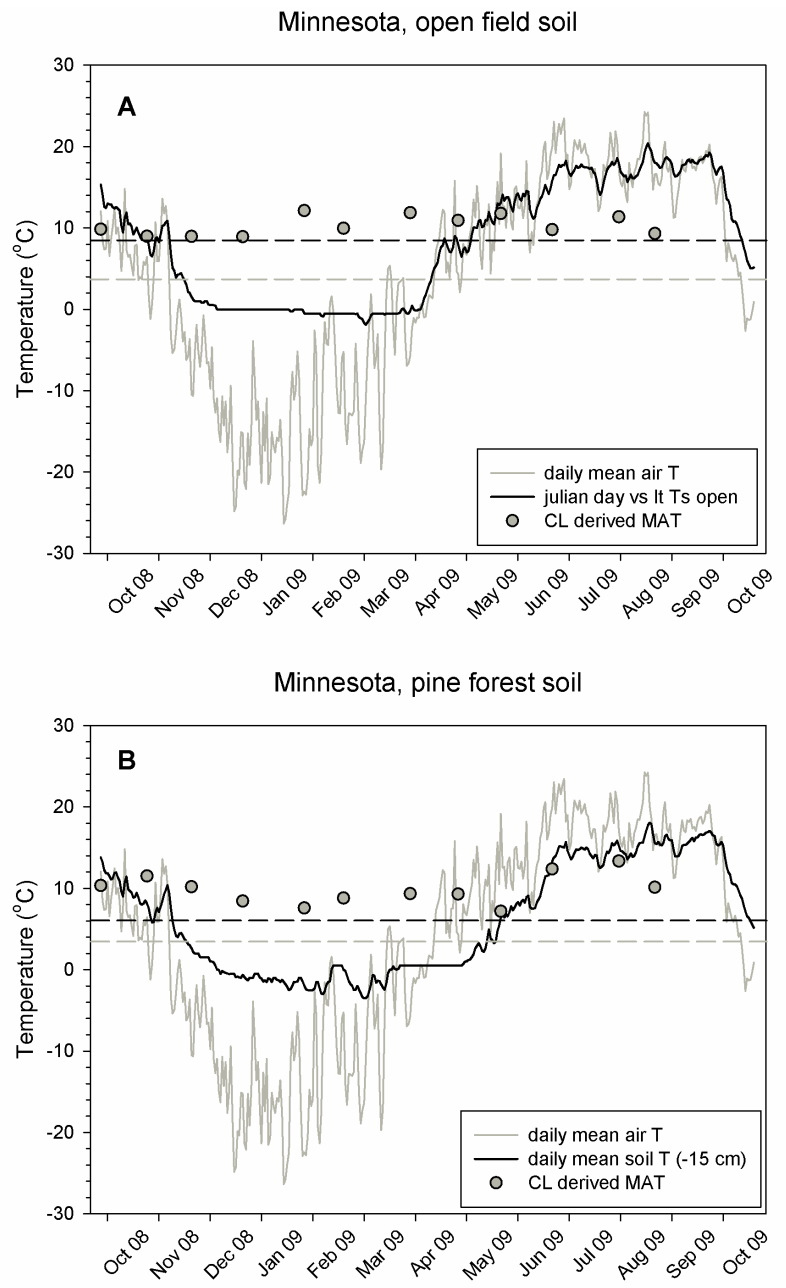

Minnesota, deciduous forest soil

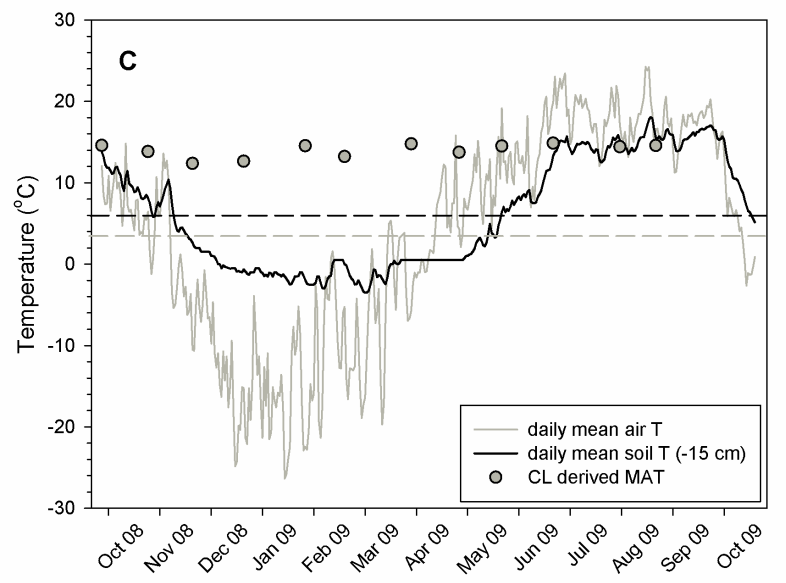


Figure 4

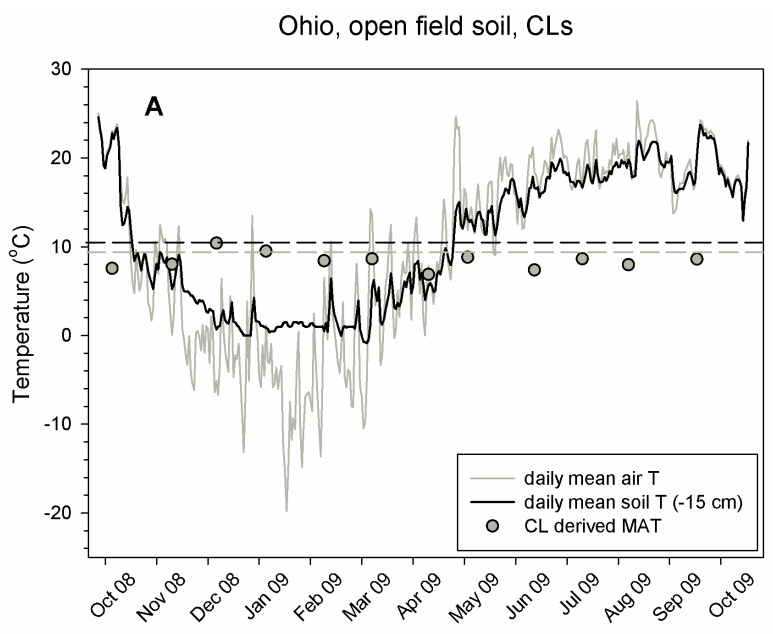

Ohio, pine forest soil, CLs

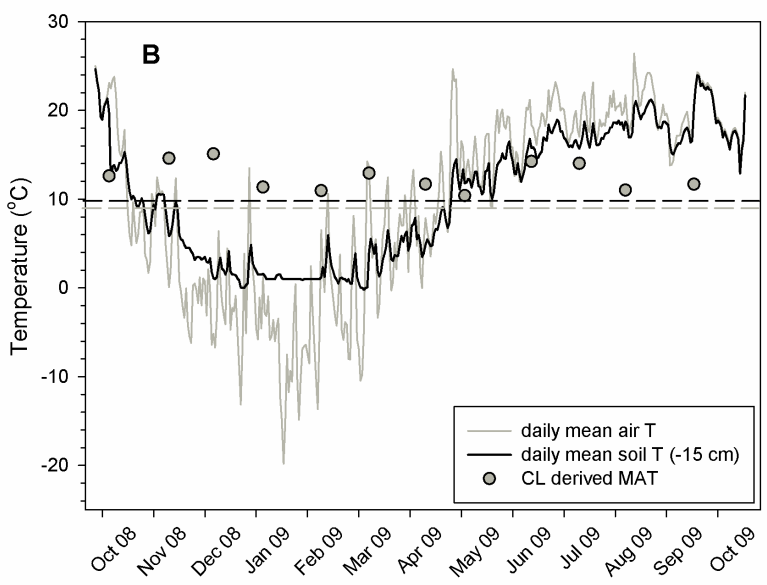

Ohio, deciduous forest soil, CLs

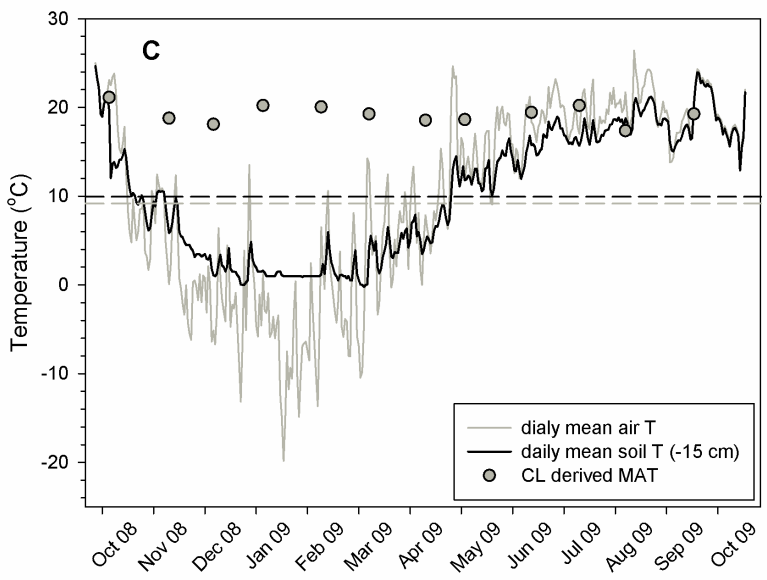


Figure 5

MAT estimates grassland soil Texel

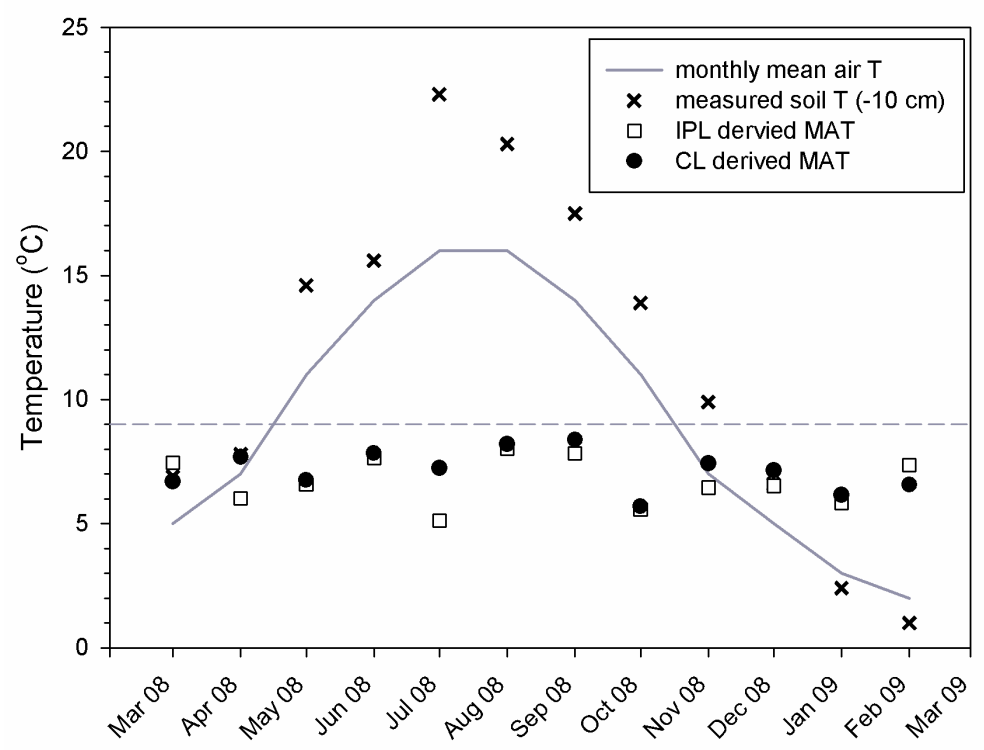


Figure 6

MAT estimates Rowden Moor grassland soil

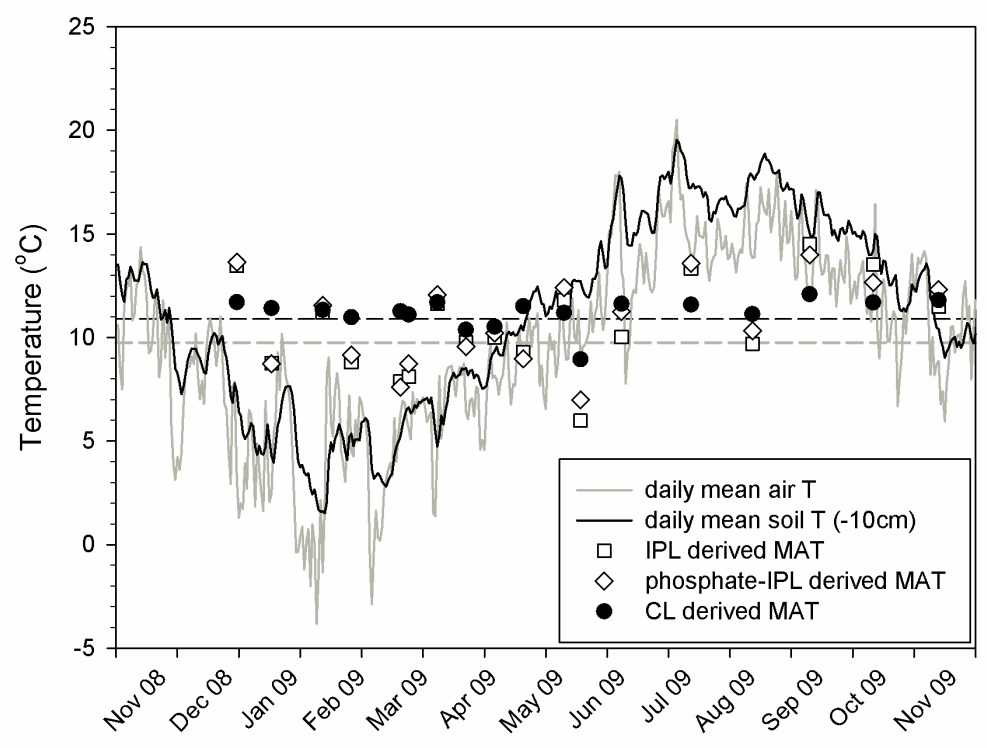

